\title{
Structure of outer arm dynein molecule in respiratory cilia suggests an alternative mechanism of force generation
}

\author{
H Ueno ${ }^{1,2 *}$, H Bui ${ }^{2}$, T Ishikawa ${ }^{3}$, Y Imai $^{3}$, T Yamaguchi $^{3}$, T Ishikawa $^{2}$ \\ From Cilia 2014 - Second International Conference \\ Paris, France. 18-21 November 2014
}

\section{Background}

Cilia are microtubule (MT)-based organelles that extend from the surface of eukaryotic cells. The ciliary movement is generated by microtubule (MT) sliding with axonemal dynein motors, and plays important roles in cell migration and generation of external fluid flow. Since cilia have diverse roles in many tissues and organs in mammal, defects in ciliary activity causes a number of diseases called ciliopathy.

\section{Objective}

In the ciliary outer dynein arm, two heavy chains produce force during ciliary beating. However, it is still unknown how the ciliary dynein translocate the microtubule using the two different heads.

\section{Methods}

Here, we analyzed the conformational change and its distribution in each dynein head of mouse respiratory cilia by cryo-electron tomography and image processing. ciliary heterodimeric dynein translocates a microtubule by moving with short steps.

\section{Conclusion}

This indicates that, in contrast to the hand-over-hand motion of cytoplasmic dynein, during ciliary bending axonemal dynein translocates microtubules by moving with short steps.

\section{Authors' details}

${ }^{1}$ Aichi University of Education, Kariya, Japan. ${ }^{2}$ Paul Scherrer Institute, Villigen PSI, Switzerland. ${ }^{3}$ Tohoku University, Sendai, Japan.

Published: 13 July 2015

\section{doi:10.1186/2046-2530-4-S1-P78}

Cite this article as: Ueno et al:: Structure of outer arm dynein molecule in respiratory cilia suggests an alternative mechanism of force generation. Cilia 2015 4(Suppl 1):P78.

\section{Results}

Most of two heads were in the same form and tightly packed in the non-nucleotide condition, whereas they are dissociated and alternatively moves in the presence of nucleotide. The external side of outer dynein arm shifts toward the neighboring B-tubule and the proximal end of axoneme, while the internal side of head only shifts toward the proximal end. In a significant number of dyneins in the presence of ADP.Vi, two heads overlap each other in the proximal shifting form, indicating that

${ }^{1}$ Aichi University of Education, Kariya, Japan

Full list of author information is available at the end of the article

Submit your next manuscript to BioMed Central and take full advantage of:

- Convenient online submission

- Thorough peer review

- No space constraints or color figure charges

- Immediate publication on acceptance

- Inclusion in PubMed, CAS, Scopus and Google Scholar

- Research which is freely available for redistribution 